\title{
Role of Some Biochemical and Genetic Markers in Predicting The Severity of Brain Injury
}

\author{
Nagwa M. Ghandour ${ }^{1 *}$, Mohamed A. Ragaee $^{2}$, Randa T.Hanna ${ }^{3}$
}

\begin{tabular}{|c|c|}
\hline & ABSTRACT \\
\hline $\begin{array}{l}\text { KEYWORDS } \\
\text { Brain trauma, } \\
\text { Visfatin gene, } \\
\text { Biomarkers, } \\
\text { Enolase. }\end{array}$ & $\begin{array}{l}\text { Head trauma is one of common injury related mortality and morbidity. Blood } \\
\text { biomarkers are valuable tools for the identification and characterization of initial } \\
\text { injury and secondary pathological processes for traumatic brain injury (TBI). This } \\
\text { study evaluated the performance of a recently developed visfatin and its genetic } \\
\text { marker and its correlation with other blood circulating biomarkers that reflect } \\
\text { specific pathological mechanisms including neuro inflammation, neuron injury and } \\
\text { oxidative damage in moderate to severe TBI patients. Peripheral blood was taken } \\
\text { from TBI patients (n=78) at hospital admission, maximum } 6 \text { hours post-injury. } \\
\text { Severity and neurological outcome were assessed using the extended Glasgow Coma } \\
\text { Scale (GCS) and blood level of: visfatin and its gene, neuron specific enolase (NSE), } \\
\text { malondialdehyde (MDA), superoxide dismutase (SOD) and gluthione (GSH). } \\
\text { Concentrations of visfatin, NSE and MDA were significantly higher in TBI patients } \\
\text { compared to control group, while SOD and GSH were decreased in TBI patients } \\
\text { compared to control group. Visfatin was positively correlated with NSE and MDA, } \\
\text { while there was negative correlation with SOD and GSH. Regarding visfatin } \\
\text { genotype, CC genotype had the highest plasma concentrations of visfatin, NSE and } \\
\text { MDA and lowest concentrations of SOD and GSH. These concentrations did not } \\
\text { significantly differ between the variant genotypes CT and TT. In conclusion blood } \\
\text { level of visfatin and its genetic marker in correlation with other blood biomarkers } \\
\text { can be used for prediction of severity of TBI cases. }\end{array}$ \\
\hline
\end{tabular}

\section{Introduction}

Traumatic brain injury (TBI) is a critical public health problem throughout the world (Roozenbeek et al., 2013). It will become the third cause of death and disability in the general population by the year 2030 (Rai et al., 2017). Early determination of injury severity is important in order to improve care, balance benefits and risks of early treatment options. Existing predictors include age, Glasgow Coma Scale (GCS), pupil response and grading of

$\overline{{ }^{(l)} \text { Forensic Medicine and Clinical Toxicology }}$ Department, Faculty of Medicine - Assiut University, Egypt.

${ }^{(2)}$ Neurosurgery Department, Faculty of Medicine Assiut University, Egypt.

${ }^{(3)}$ Medical Biochemistry Department, Faculty of Medicine - Assiut University, Egypt. Faculty of Medicine - Assiut University, Egypt

*E-mail of corresponding author:n_ghandour10@yahoo.com. extent/type of TBI damage on imaging (Raj et al., 2014).

In recent years, researches have been devoted to find biomarkers that can improve the predictive capacity of demographic, clinical and imaging factors (Strathmann et al., 2014). Kövesdi et al. (2010) ascertained that biomarkers to be specific and sensitive, it should be proportional to the mechanical impact and the extent of the injury, as well as, appear rapidly in the blood.

The most established approach to develop biomarkers for brain trauma is to identify proteins abundant in brain cells e.g.: neuronspecific enolase (NSE) and Ubiquitin Cterminal hydrolase-L1 (UCH-L1) in neurons; S100B and glial fibrillary acidic protein (GFAP) in astroglia. The second approach is to study inflammatory cytokines, oxidized lipids and metabolites (Bogoslovsky et al., 2016). 
The NSE is a glycolytic protein. It can be used as an indicator of functional levels and mortality rates after brain injury (Böhmer et al., 2011). This protein is passively released into the extracellular space only under pathological conditions during cell destruction (Papa et al., 2015) and its concentration rises to its peak 6 hours after the injury (Woertgen et al., 2001).

Visfatin is a newly identified proinflammatory adipokine which was found to be produced and secreted in visceral fat. Many researchers reported that it has a close relationship with inflammation and tissue damage repair (Xiao et al., 2015). Circulating visfatin concentrations have been reported to be elevated in patients with type 2 diabetes mellitus, obesity, ischemic stroke and rheumatoid arthritis (Huang et al., 2013).

Genetic polymorphism $\mathrm{C}>\mathrm{T}$ located in the visfatin gene promoter has been suggested to be associated with the regulation of visfatin expression in some inflammatory illness (Chen et al., 2012). Weng et al. (2013) found that the visfatin gene-mutation-induced various genotypes were greatly related with the conditions of patients with TBI.

The brain is highly sensitive to oxidative stress. Under physiological conditions, the defense system is able to prevent the formation or scavenge of these harmful molecules, protecting tissues from oxidative damage. In brain injury, there is a considerable increase in the production of free radicals (Arent et al., 2014).

The main objective of this study was to evaluate the role of plasma visfatin and its gene mutation in patients with TBI, and its correlation to changes of other blood biomarkers e.g. neuron specific enolase (NSE), Malondialdehyde (MDA), superoxide dismutase (SOD) and glutathione (GSH). Also, this study aimed to estimate the possible value of these markers for the prediction of TBI severity.

\section{Patients and Methods}

\section{Patients, design and procedures:}

The study group consisted of 78 brain trauma patients admitted to the Department of Neurosurgery, Assiut University Hospital. Upon admission at trauma emergency room, patients were evaluated. The excluded patients were described by Papa et al. 2015 as they were less than 18 years of age, admission time $>6 \mathrm{~h}$, existing previous head trauma, neurological disease including ischemic or hemorrhagic stroke, presence of prior systemic diseases as liver cirrhosis, diabetes mellitus, malignancy, chronic heart or lung disease, hypertension and obesity as well as use of anticoagulant medication.

The patients were divided according to Glasgow Coma Scale (GCS) criteria. GCS (13-15) was considered mild; GCS (9-12) was moderate while GCS (3-8) was considered severe injury (Di Battista et al., 2015). Head CT scan was done for all patients. Demographic data (age, sex) was obtained. To highlight the results, 20 healthy people were enrolled as control group.

\section{Blood sample collection and analysis:}

Venous blood $(10 \mathrm{ml})$ was drawn from patients on admission and from control group, into EDTA glass tubes. Eight milliliters were centrifuged at 1500 round per minute (rpm) for 20 min to collect plasma. Plasma was stored at $-70{ }^{\circ} \mathrm{C}$ until analysis of different biochemical markers. The remaining $2 \mathrm{ml}$ was stored at -70 ${ }^{\circ} \mathrm{C}$ until DNA extraction.

(A) Measurement of visfatin and Neuron specific Enolase (NSE):

Enzyme linked immunosorbent assay technique (ELISA) was performed to measure plasma concentrations of visfatin and NSE, 
using commercial kit (Cat No.30092, Ray Biotech,3607, Parkway Lane Suite 200, Norcross) for visfatin and commercial kit (Cat no. 153308, MyBioSour, P.O. Box San Diego, California, United States) for NSE following the instructions supplied with the kits. Samples were measured as duplicate for single experiment.

(B) Measurement of oxidative markers:

Analysis of lipid peroxides malondialdehyde derivative (MDA), as an index for oxidative stress, superoxide dismutase (SOD) and glutathione (GSH), as antioxidants, were done by spectrophotometry.

Malondialdehyde derivative was determined by chemical method according to Ohkawa et al. (1979) which based on the oxidation of zylenol orange into purple colored chromogen that is proportional with the peroxide content in the presence of ferrous sulfate as a catalyzer. It was measured at 532 $\mathrm{nm}$ in spectrophotometer.

Superoxide dismutase activity was determined according to its ability to inhibit the auto-oxidation of epinephrine at alkaline media as described by Misra and Fridovich (1972). Spectrum was measured at $480 \mathrm{~nm}$.

Glutathione was assayed according to method of Jollow et al. (1974) which relies on mixing $1 \mathrm{~mL}$ of sample with $1.0 \mathrm{~mL}$ of sulfosalicylic acid (4\%). The samples were incubated at $4^{\circ} \mathrm{C}$ for at least $1 \mathrm{~h}$, and then centrifuged at $1200 \mathrm{rpm}$ for $15 \mathrm{~min}$ at $4^{\circ} \mathrm{C}$. The reaction mixture contained $0.4 \mathrm{~mL}$ of filtered sample, $2.2 \mathrm{~mL}$ phosphate buffer $(0.1 \mathrm{M}, \mathrm{pH}$ 7.4), and $0.4 \mathrm{~mL}$ dithionitrobenzoic acid (DTNB) in a total volume of $3 \mathrm{~mL}$. The yellow color developed was read immediately at $412 \mathrm{~nm}$ by spectrophotometer.
(C) DNA extraction and genotyping:

Genomic DNA extraction was done using the Patho Gene-spin ${ }^{\mathrm{TM}}$ DNA/RNA Extraction Kit (iNtRON Biotechnology. Made in Korea). Lot. No. 11650150. Cat. No.17154 according to manufacturer's guidelines and stored at $80^{\circ} \mathrm{C}$ until genotyping.

Visfatin gene polymorphisms were studied by PCR followed by RFLP as described by Wang et al. (2011). The primer used was 5'TGTTTCAAACCTCGTTGCTGA-3' and reverse 5'AGTGATGGTGGTGGTGGTA-3'. PCR products were digested and visualized in $3 \%$ agarose gel electrophoresis. The genotypes of visfatin were characterized as TT (283bp), TC (283bp, $218 \mathrm{bp})$, and CC (218bp) as reported by Xiao et al. (2015).

\section{Statistical Analysis}

Statistical analysis was performed with SPSS 20.0 (SPSS Inc. Chicago, USA).

The categorical variables are presented as percentages, and the continuous variables are presented as mean \pm standard deviation. Comparisons were made using Chi-square test or Fisher exact test for categorical data and unpaired Student t-test and Mann-Whitney for continuous variables. When $\mathrm{p}<0.05$, the difference was statistically significant. The correlation, of visfatin and its gene with other markers, was assessed by Spearman's correlation coefficient.

\section{Ethical considerations}

The study was reviewed and approved by Research and Ethical committee of Faculty of Medicine, Assiut University (no:17300207). Written informed consent was taken from control group and relatives of TBI who participated in the study. Confidentiality of the data was guaranteed. 


\section{Results}

\section{Patient characteristics:}

Seventy eight patients, admitted to Neurosurgery Department with an isolated head trauma, were included in the study. Twenty healthy people were included as control group. Patients were 50 males and 28 females with mean age of $(52.38 \pm 1.65)$ years. The control group was 13 males and 7 females with mean age of $(53.86 \pm 2.7 \mathrm{y})$. There were no significant differences in both sex and age among patients and control subjects (both $\mathrm{p}>$ $0.05)$. These characteristics were listed in the table (1). Regarding GCS criteria, they were 52 moderate TBI patients and 26 severely injured. The causes of TBI and CT scan results of patients were shown in table (2). Motor car accident (MCA) represented the major cause of trauma in 20 cases $(25.6 \%)$, followed by motor bike accident (MBA) in 16 cases (20.5\%), while Fall on ground (FOG) and Fall on stairs (FOS) were the cause in 4 injuries $(5.1 \%)$ for each. Regarding CT scan results, sixteen patients $(20.5 \%)$ showed brain edema, and eight cases (10.3\%) showed contusion. Extradural hemorrhage represented the highest type of intracranial hemorrhage among included patients, in 20 cases. Depressed fracture was found in 6 cases $(7.7 \%)$.

\section{Biochemical markers:}

Visfatin concentration was significantly elevated $(p<0.001)$ in severe TBI patients as compared to moderate TBI patients $(28 \pm 1.68$ $\mu \mathrm{g} / \mathrm{L}, \quad 25 \pm 2.09 \mu \mathrm{g} / \mathrm{L})$ respectively. Its concentration was highly significantly elevated $(\mathrm{p}<0.0001)$ in both TBI groups as compared to control $(7.62 \pm 0.87 \mu \mathrm{g} / \mathrm{L})$. Also, NSE concentration was significantly higher $(\mathrm{p}<$ $0.0001)$ in severe TBI patients as compared to moderate TBI patients $(20.47 \pm 3 \mathrm{ng} / \mathrm{ml}, 13.49 \pm$ $2.66 \mathrm{ng} / \mathrm{ml}$ ) respectively. Its concentration was highly significantly elevated $(p<0.0001)$ in both TBI groups as compared to control( $4.3 \pm$ $0.52 \mathrm{ng} / \mathrm{ml}$ ) as shown in table (3) and figure(1).

Level of MDA was significantly elevated $(\mathrm{p}<0.001)$ in severe TBI patients as compared to moderate TBI patients $(6.88 \pm 0.58 \mu \mathrm{mol} / \mathrm{L}$, $5.33 \pm 0.08 \mu \mathrm{mol} / \mathrm{L})$ respectively. It was significantly elevated $(\mathrm{p}<0.001)$ in severe TBI patients when compared to control $(5.12 \pm 0.76$ $\mu \mathrm{mol} / \mathrm{L})$, while, this elevation was nonsignificant in moderate TBI patients compared to control. Regarding SOD, its concentration was significantly decreased $(p<$ 0.01 ) in severe TBI patients as compared to moderate TBI patients $(245.12 \pm 24.2 \mathrm{U} / \mathrm{L}$, $276.097 \pm 30.8 \mathrm{U} / \mathrm{L})$. Glutathione was highly significant decreased $(\mathrm{p}<0.0001)$ in severe TBI patients as compared to moderate TBI patients $(112.07 \pm 2.09 \mu \mathrm{mol} / \mathrm{L}, 119.26 \pm 2.7$ $\mu \mathrm{mol} / \mathrm{L})$. Both, SOD and GSH, were highly significantly decreased $(p<0.0001)$ as compared to control $(304.17 \pm 27.17 \mathrm{U} / \mathrm{L}$ and $151.64 \pm 9.9 \mu \mathrm{mol} / \mathrm{L})$ respectively, as shown in table (4) and figure (2).

The correlation of plasma visfatin concentration in TBI patients and other biochemical parameters was illustrated in table (5). Visfatin was positively correlated with $\mathrm{NSE}(\mathrm{r}=0.699, \mathrm{p}<0.01)$ and MDA $(\mathrm{r}=0.338$, $\mathrm{p}<0.05)$. While there was negative correlation with SOD $(\mathrm{r}=-0.156$, non-significant $)$ and GSH $(r=-0.588, p<0.01)$.

\section{Visfatin genotyping:}

Visfatin gene $\mathrm{C}>\mathrm{T}$ locus had three genotypes: TT was characterized at $283 \mathrm{bp}, \mathrm{TC}$ at $283 \mathrm{bp}, 218 \mathrm{bp}$ and CC at 218bp (Figure 3).

Genotype distribution showed no significance between the patients and the control group $(\mathrm{p}>0.05)$. Patients with severe TBI were mostly CC genotype $(n=22)$, while moderate TBI patients were TC and TT 
genotype carriers $(n=14$ and $n=36$, lowest SOD and GSH. While these respectively), as shown in table (6). concentrations did not differ significantly

The genotype CC had the highest plasma visfatin, NSE and MDA concentrations and between the variant genotypes $\mathrm{CT}$ and $\mathrm{TT}$ (Table 7 and Figure 4).

Table (1): Characteristics of the studied groups

\begin{tabular}{|c|c|c|c|}
\hline & $\begin{array}{c}\text { Patients }(\mathbf{n}=\mathbf{7 8}) \\
\text { Mean } \pm \text { SD }\end{array}$ & $\begin{array}{c}\text { Control }(\mathbf{n}=\mathbf{2 0}) \\
\text { Mean } \pm \text { SD }\end{array}$ & \multirow{2}{*}{ p value } \\
\hline \multirow{2}{*}{ Age } & $52.38 \pm 1.65$ & $53.86 \pm 2.7$ & $\mathrm{~ns}(\mathrm{p}=0.647)$ \\
\hline \multirow{2}{*}{ Sex } & 50 males $(64.1 \%)$ & 13 males $(65 \%)$ & \multirow{2}{*}{$\mathrm{ns}(\mathrm{p}=0.752)$} \\
\cline { 2 - 3 } & 28 females $(35.9 \%)$ & 7 females $(35 \%)$ & \\
\hline
\end{tabular}

SD: Standard deviation, n: number, ns: non-significant

Table (2): Causes of trauma and results of head CT scan in TBI patients ( $\mathrm{n}=78)$

\begin{tabular}{|c|c|c|c|}
\hline Causes of trauma & & $\mathbf{n}$ & $\%$ \\
\hline RTA & & 10 & 12.8 \\
\hline MCA & & 20 & 25.6 \\
\hline MBA & & 16 & 20.5 \\
\hline FOG & & 4 & 5.1 \\
\hline FFH & & 8 & 10.3 \\
\hline FOS & & 4 & 5.1 \\
\hline AFO & & 8 & 10.3 \\
\hline HO & & 8 & 10.3 \\
\hline \multicolumn{4}{|l|}{ CT scan results } \\
\hline \multirow{2}{*}{ Brain } & Edema & 16 & 20.5 \\
\hline & Contusion & 8 & 10.3 \\
\hline \multirow{3}{*}{ Intracranial hemorrhage } & SAH & 12 & 15.4 \\
\hline & EDH & 20 & 25.6 \\
\hline & ASDH & 6 & 7.7 \\
\hline \multirow{3}{*}{ Fracture } & Fissure & 5 & 6.4 \\
\hline & Depressed & 6 & 7.7 \\
\hline & Base & 5 & 6.4 \\
\hline
\end{tabular}

CT: Computed Tomography; TBI: Traumatic brain injury; n: Number; RTA (Road traffic accident);MCA (Motor car accident);MBA (Motor bike accident);FOG (Fall on ground); FFH (Fall from height); FOS (Fall on stairs); AFO (Assault from other); HO (heavy object); SAH (subarachnoid hemorrhage); EDH (extradural hemorrhage); ASDH (acute subdural hemorrhage), n: number. 
Table (3): Plasma levels of Visfatin and NSE in studied groups (moderate injured patients, severe injured patients and control).

\begin{tabular}{|c|c|c|c|}
\hline \multicolumn{2}{|c|}{$\begin{array}{ll}\text { Biochemical Markers } \\
\text { Cases }\end{array}$} & $\begin{array}{l}\text { Visfatin }(\boldsymbol{\mu g} / \mathbf{L}) \\
\text { Mean } \pm \text { SD }\end{array}$ & $\begin{array}{c}\text { Enolase (NSE) (ng/ml) } \\
\text { Mean } \pm \text { SD }\end{array}$ \\
\hline \multirow{2}{*}{ 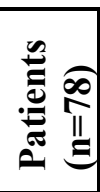 } & Moderate $(n=52)$ & 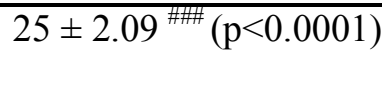 & $13.49 \pm 2.66 \quad \#(p<0.0001)$ \\
\hline & Severe $(n=26)$ & 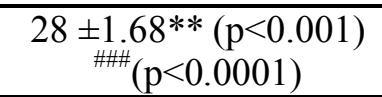 & $\begin{array}{c}20.47 \pm 3 * * *(p<0.0001) \\
\# \#(\mathrm{p}<0.0001)\end{array}$ \\
\hline \multicolumn{2}{|r|}{ Control $(n=20)$} & $7.62 \pm 0.87$ & $4.3 \pm 0.52$ \\
\hline
\end{tabular}

SD: Standard deviation, n: number, NSE: Neuron specific enolase, ${ }^{*}$ : significant difference as compared to moderately injured patients, ${ }^{\#}$ : significant difference as compared to control.
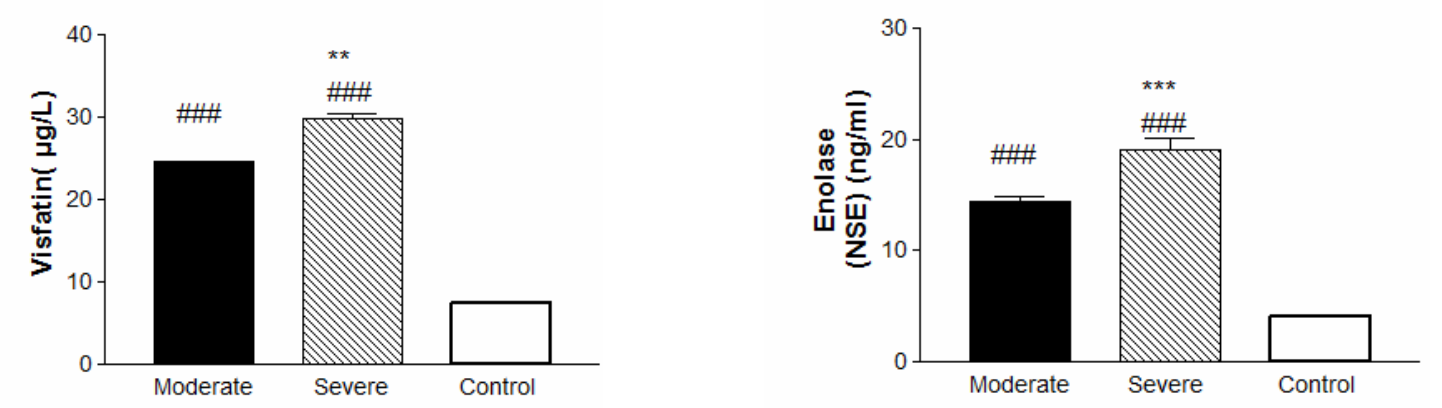

Fig. (1): Effects of traumatic brain injury on Visfatin and NSE in studied groups (moderate injured patients, severe injured patients and control). NSE: Neuron specific enolase

Table (4): Plasma levels of MDA, SOD and GSH in studied groups (moderate injured patients, severe injured patients and control).

\begin{tabular}{|c|c|c|c|c|}
\hline Cases & $\begin{array}{r}\text { Biochemical } \\
\text { Markers }\end{array}$ & $\begin{array}{c}\text { MDA }(\boldsymbol{\mu m o l} / \mathbf{L}) \\
\text { Mean } \pm \text { SD }\end{array}$ & $\begin{array}{l}\text { SOD( U/L) } \\
\text { Mean } \pm \text { SD }\end{array}$ & $\begin{array}{c}\mathbf{G S H}(\boldsymbol{\mu} \mathbf{m o l} / \mathbf{L}) \\
\text { Mean } \pm \text { SD }\end{array}$ \\
\hline \multirow[b]{2}{*}{ 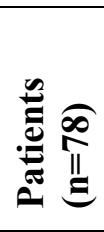 } & $\begin{array}{c}\text { Moderate } \\
(\mathrm{n}=52)\end{array}$ & $\begin{array}{c}5.33 \pm 0.08^{\mathrm{ns} \#} \\
(\mathrm{p}=0.631)\end{array}$ & $\begin{array}{c}276.097 \pm 30.8^{\#} \\
(\mathrm{p}<0.001)\end{array}$ & $\begin{array}{c}119.26 \pm 2.7^{\# \# \#} \\
(\mathrm{p}<0.0001)\end{array}$ \\
\hline & $\begin{array}{l}\text { Severe } \\
(\mathrm{n}=26)\end{array}$ & $\begin{array}{c}6.88 \pm 0.58 \\
* *(p<0.001) \\
\# \#(p<0.001)\end{array}$ & $\begin{array}{c}245.12 \pm 24.2 \\
*(p<0.01) \quad \# \#(p<0.0001)\end{array}$ & $\begin{array}{c}112.07 \pm 2.09 \\
* * *(\mathrm{p}<0.0001) \\
\# \#(\mathrm{p}<0.0001)\end{array}$ \\
\hline \multicolumn{2}{|c|}{$\operatorname{Control}(n=20)$} & $5.12 \pm 0.76$ & $304.17 \pm 27.17$ & $151.64 \pm 9.9$ \\
\hline
\end{tabular}

MDA: Malondialdehyde, SOD: Superoxide dismutase, GSH: Glutathione, SD: Standard deviation, n: number, ns nonsignificant, * :significant difference as compared to moderately injured patients, \#: significant difference as compared to control 

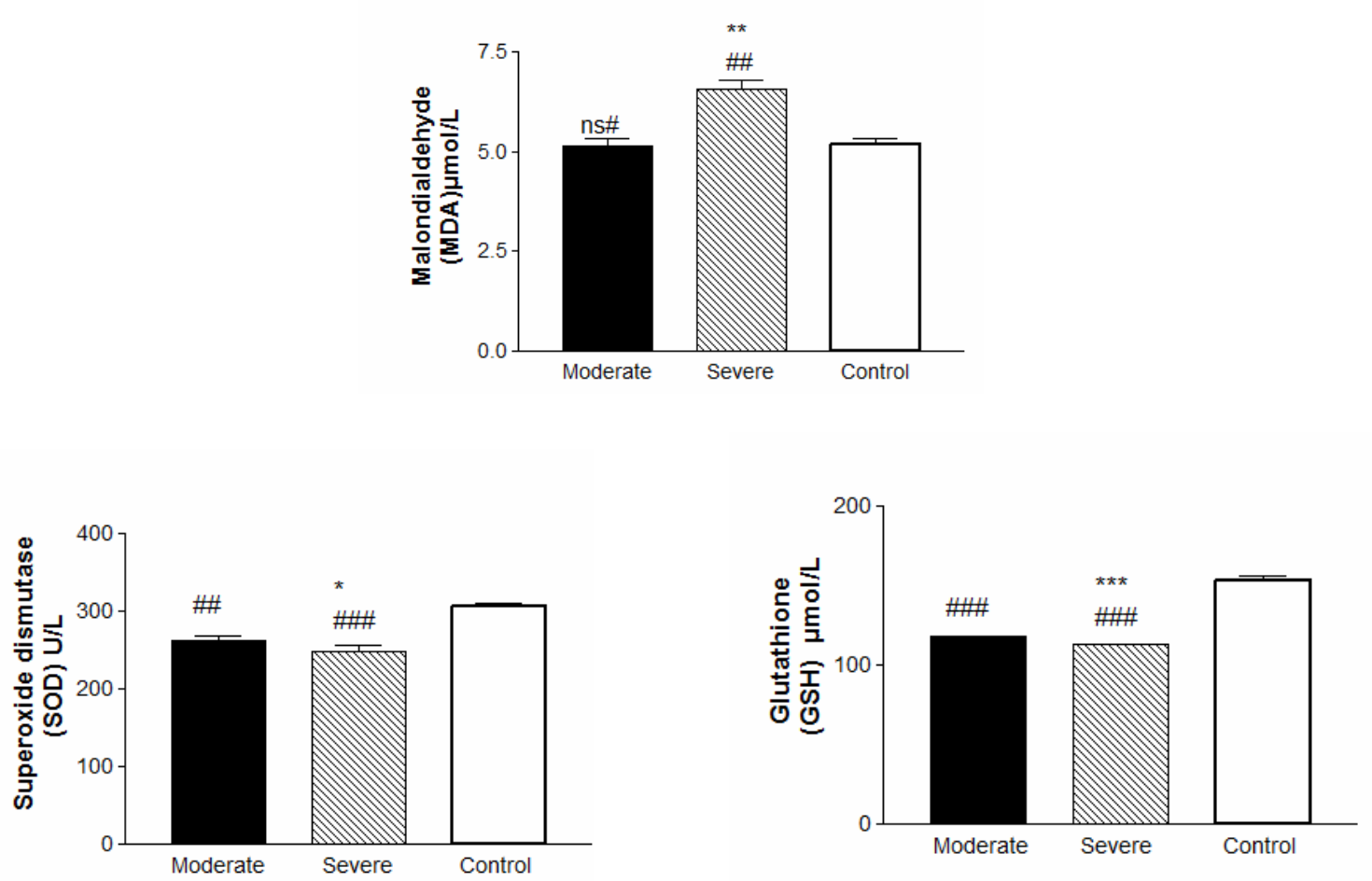

Fig. (2): Effects of traumatic brain injury on MDA, SOD and GSH in studied groups (moderate injured patients, severe injured patients and control). MDA: Malondialdehyde, SOD: Superoxide dismutase, GSH: Glutathione.

Table (5): Correlation between Plasma visfatin concentration and other biochemical markers traumatic brain injured patients:

\begin{tabular}{|c|c|c|c|c|}
\hline Biochemical Markers & $\begin{array}{l}\text { Enolase } \\
\text { (NSE) }\end{array}$ & $\begin{array}{l}\text { Malondialdehyde } \\
\text { (MDA) }\end{array}$ & $\begin{array}{c}\text { Superoxidedismutase } \\
\text { (SOD }\end{array}$ & $\begin{array}{c}\text { Glutathione } \\
\text { (GSH) }\end{array}$ \\
\hline Visfatin & $\begin{array}{c}0.699^{* *} \\
(p<0.01) \\
\end{array}$ & $\begin{array}{c}0.338^{*} \\
(\mathrm{p}<0.05) \\
\end{array}$ & $\begin{array}{c}-0.156^{\mathrm{ns}} \\
(\mathrm{p}=0.266) \\
\end{array}$ & $\begin{array}{l}-0.588^{* *} \\
(\mathrm{p}<0.01)\end{array}$ \\
\hline Enolase (NSE) & & $\begin{array}{l}0.484^{* *} \\
(p<0.01)\end{array}$ & $\begin{array}{l}-0.531^{* *} \\
(\mathrm{p}<0.01)\end{array}$ & $\begin{array}{l}-0.717^{* *} \\
(p<0.01)\end{array}$ \\
\hline $\begin{array}{l}\text { Malondialdehyde } \\
\text { (MDA) }\end{array}$ & & & $\begin{array}{c}-0.221^{\mathrm{ns}} \\
(\mathrm{p}=0.112) \\
\end{array}$ & $\begin{array}{l}-0.530^{* * *} \\
(\mathrm{p}<0.01)\end{array}$ \\
\hline $\begin{array}{l}\text { Superoxidedismutase } \\
\text { (SOD) }\end{array}$ & & & & $\begin{array}{c}0.146^{\text {ns }} \\
(p=0.295)\end{array}$ \\
\hline
\end{tabular}

NSE: Enolase, MDA: Malondialdehyde, SOD: Superoxide dismutase, GSH: Glutathione, Spearman Correlation / Sig. (2-tailed)

**. Correlation is significant at the 0.01 level (2-tailed).

*. Correlation is significant at the 0.05 level (2-tailed). 
Table (6): Distribution of genotypes in each group

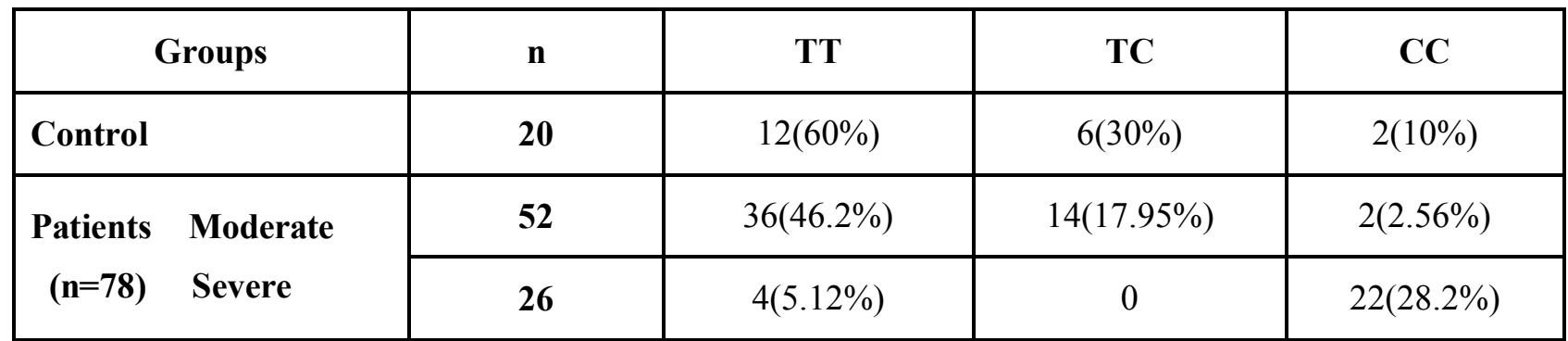

n: number

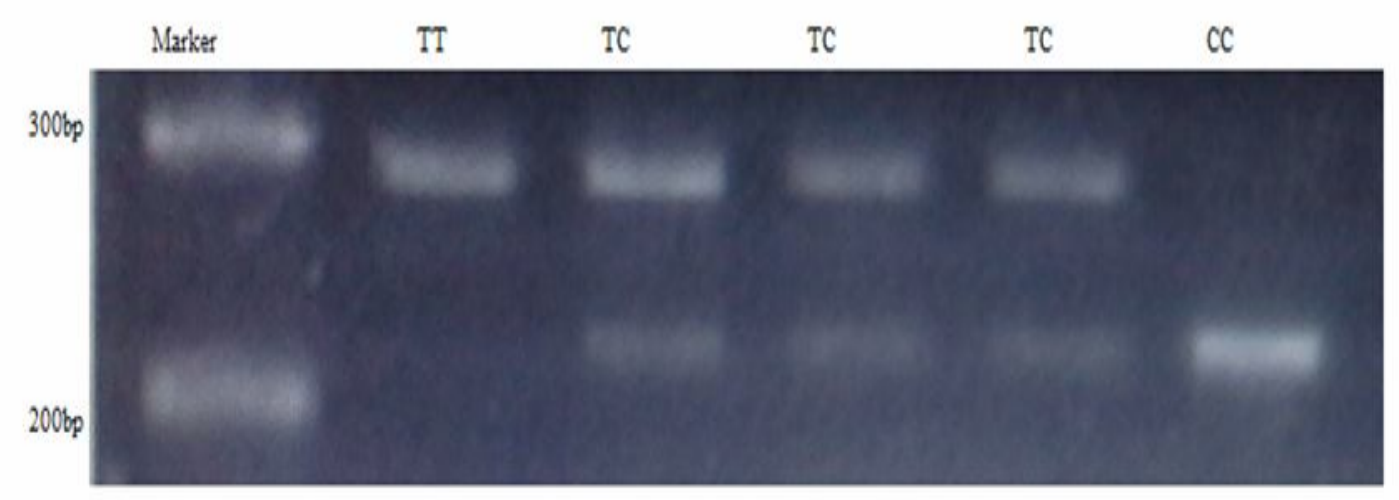

Fig. (3): Visfatin genotyping

Table (7): Levels of different biochemical markers among each genotype in brain trauma patients:

\begin{tabular}{|l|c|c|c|}
\hline \multicolumn{1}{|c|}{ Genotype } & TT & TC & CC \\
\hline Biochemical Markers & $19.4 \pm 8.6$ & $\begin{array}{c}18.5 \pm 8.7^{\mathrm{bns}} \\
(\mathrm{p}=0.940)\end{array}$ & $\begin{array}{c}33 \pm 9.6^{\mathrm{a}^{* * *}} \\
(\mathrm{p}<0.0001)\end{array}$ \\
\hline Visfatin $(\mu \mathrm{g} / \mathrm{L})$ & $11.5 \pm 5.6$ & $\begin{array}{c}9.9 \pm 4.7^{\mathrm{bns}} \\
(\mathrm{p}=0.671)\end{array}$ & $\begin{array}{c}17.84 \pm 6.1^{\mathrm{a}^{* *}} \\
(\mathrm{p}<0.001)\end{array}$ \\
\hline Enolase (NSE) (ng/ml) & $5.85 \pm 0.79$ & $\begin{array}{c}5.69 \pm 1.05^{\mathrm{bns}} \\
(\mathrm{p}=0.606)\end{array}$ & $\begin{array}{c}6.5 \pm 0.78^{\mathrm{a}^{*}} \\
(\mathrm{p}<0.01)\end{array}$ \\
\hline $\begin{array}{l}\text { Malondialdehyde } \\
\text { (MDA) } \mu \text { mol/L }\end{array}$ & $288.84 \pm 56.4$ & $\begin{array}{c}309.23 \pm 39.2^{\mathrm{bns}} \\
(\mathrm{p}=0.208)\end{array}$ & $\begin{array}{c}237.65 \pm 72.7^{\mathrm{a}^{*}} \\
(\mathrm{p}<0.01)\end{array}$ \\
\hline $\begin{array}{l}\text { Superoxide dismutase } \\
\text { SOD) U/L }\end{array}$ & $128.82 \pm 17.7$ & $\begin{array}{c}127.81 \pm 17.5^{\mathrm{bns}} \\
(\mathrm{p}=0.939)\end{array}$ & $\begin{array}{c}119.92 \pm 12.2^{\text {ans }} \\
(\mathrm{p}=0.182)\end{array}$ \\
\hline $\begin{array}{l}\text { Glutathione }(\mathrm{GSH}) \\
\mu \mathrm{mol} / \mathrm{L}\end{array}$ & \multicolumn{2}{|c|}{} \\
\hline
\end{tabular}

${ }^{a}$ Kruskal Wallis test (significance among 3groups)

${ }^{\mathrm{b}}$ Mann-Whitney test (significance among 2groups, TC vs TT) 

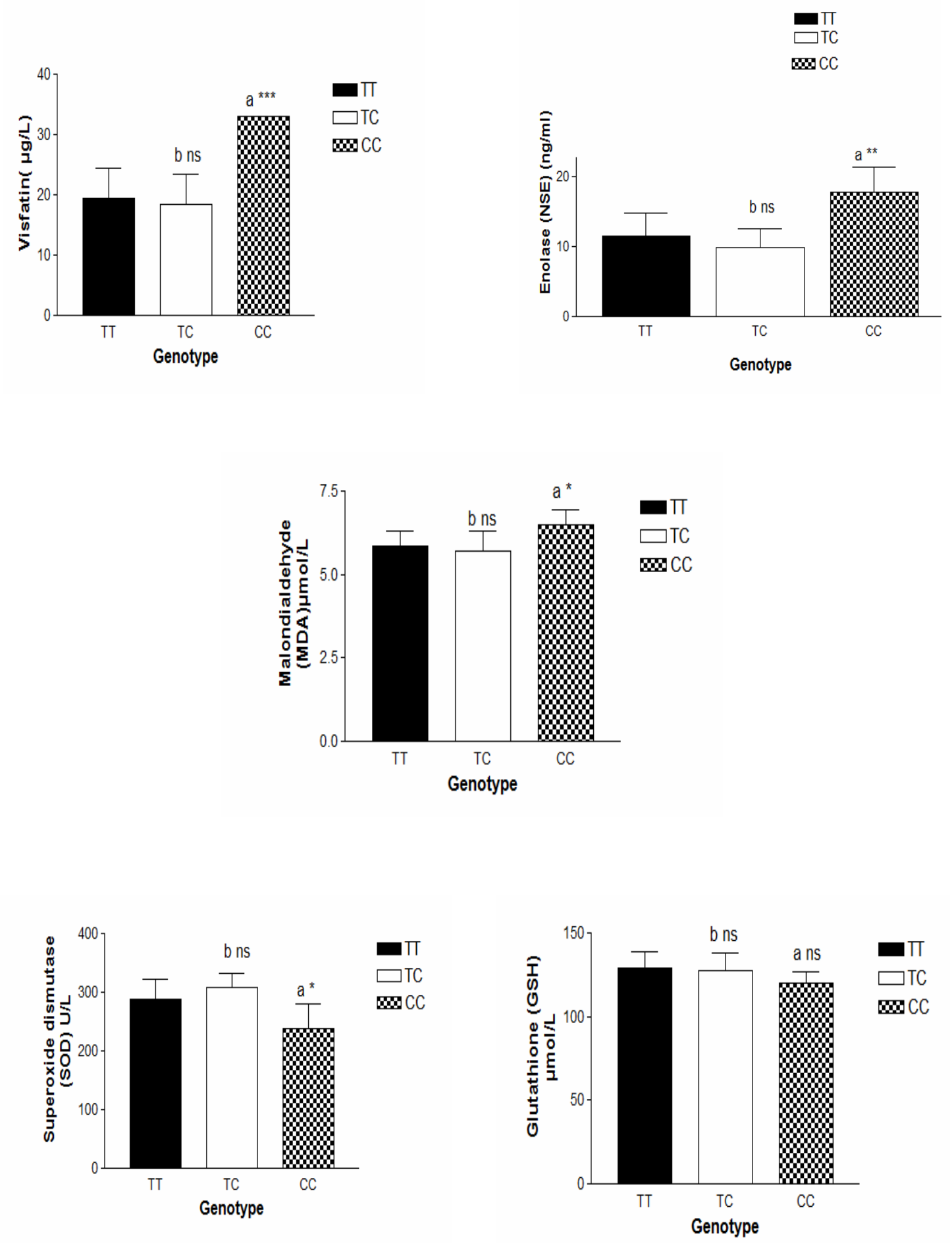

Fig. (4): Levels of different biochemical markers among each genotype in brain trauma patients:

${ }^{\text {a }}$ Kruskal Wallis test (significance among 3groups)

${ }^{\mathrm{b}}$ Mann-Whitney test (significance among 2groups, TC vs TT) 


\section{Discussion}

Head trauma is one of common injury related mortality and morbidity. Traumatic brain injury patients represent the greatest challenge for accurate diagnosis and outcome prediction especially in the acute setting "within $24 \mathrm{~h}$ after injury" (Undén et al., 2015).

Prognosis can be assessed by many predictors such as age, neurological examination of some clinical variables e.g. Glasgow Coma Scale (GCS), loss of consciousness (LOC) and posttraumatic amnesia (PTA). In addition, neuroimaging tools such as MRI and CT scanning can be used (Schaan et al., 2002 and Balestreri et al., 2004).

In brain trauma, blood biomarkers are preferable than CSF for accurate and rapid assessments, as they are cost effective; and require minimally invasive sample collection, compared to CSF collected by invasive method as lumbar puncture (LP) or ventriculostomy (Katawa et al., 2016).

Circulating serological biochemical markers may be associated with secondary injury progression and poor prognosis. A single factor has insufficient predictive value to distinguish patients who will do poorly from those who will be good (Mushkudiani et al., 2008). Thus, for accuracy, a multi-marker approach to characterize traumatic brain injured patients outcome has been advocated and may increase diagnostic and prognostic accuracy and may prove multi-systemic character of secondary injury pathology (Di Battista et al., 2015).

This research aimed to diagnose traumatic brain injury by assessing five blood biomarkers, each associated with a specific traumatic brain related injury process : Visfatin as pro-inflammatory adipokine, as well as Genetic polymorphism $\mathrm{C}>\mathrm{T}$ located in the visfatin gene promoter for regulation of visfatin expression; neuron specific enolase (NSE) relating to neuronal injury; lipid peroxides malondialdehyde derivative (MDA) for oxidative stress; superoxide dismutase (SOD) and glutathione (GSH), as antioxidants. Also, to correlate the change in plasma visfatin to other biomarkers, as well as, to clinical severity after traumatic brain injury, for which, no published information exists to date about this.

Seventy eight patients were included in the study. Males were more than females (as most TBI cases were due to outdoor activities). Regarding GCS criteria, they were 52 moderate TBI patients and 26 severely injured .No mild cases were evaluated, as Assiut University Hospital (AUH) is a big referral hospital for all Upper Egypt governorates. The emergency units in AUH are tertiary level units receiving all types of trauma, either direct or referred from other hospitals. Therefore, they admit patients to undergo operative treatment or admitted to the intensive care in trauma unit (Abdel-Hameed et al., 2017).

Visfatin has a vital role in the pathogenesis of vascular inflammation and it was closely related with inflammation and repair after tissue damage (Wang et al., 2011). Thrombin and fibrin degradation products can induce a series of inflammatory reactions after traumatic brain injury, so the generation and the concentration of most inflammatory factors increase (Lozano et al., 2015).

In the presented study, visfatin concentration was significantly elevated in severe TBI patients as compared to moderate TBI patients .Its concentration was highly 
significantly elevated in both TBI groups as compared to control.

This was consistence with Chen et al. (2012), who reported for the first time significantly higher visfatin levels in patients with severe TBI. In addition, Weng et al. (2013) demonstrated highest plasma visfatin and C-reactive protein concentrations among head injured patients.

The NSE is a marker present in the neuron cell body (Selakovic et al., 2005). Ogata and Tsuganezawa (1999) ascertained that NSE is a surrogate marker of neuronal damage. They found elevated NSE with injured axons in the corpus callosum of patients sustaining fatal diffuse axonal injury, while, NSE is nearly undetectable in patients with non-injured axons or control subjects.

The results of this study showed that NSE concentration was also, significantly higher in severe TBI patients as compared to moderate TBI patients. Its concentration was highly significantly elevated in both TBI groups as compared to control.

In agreement with the presented study, Lee et al. (2017) reported that NSE could be used as an indicator of functional levels and mortality rates after head injury. Vos et al. (2004) found elevated NSE levels, correlated with the injury severity score and CT findings and were significantly higher in in patients with poor outcome post injury. McKeating et al. (1998) found that NSE in serum peaks within $6 \mathrm{~h}$ after injury and decreases during the subsequent hours. Multiple studies have shown that serum NSE levels spike after moderate to severe head injury (Skogseid et al., 1992; de Kruijk et al., 2001; Anand and Stead, 2005; Guzel et al., 2008; Meric et al., 2010 and Cheng et al., 2014).
In addition, Di Battista et al. (2015) found unfavorable neurological outcome was associated with elevations in six of the seven markers including neuron specific enolase (NSE), and lipid peroxidation.

In controversy with that, Shahim et al. (2014) reported no difference in serum NSE in post-concussion values among 35 concussed ice hockey players. This may be explained as in concussion there is no actual damage or injury to brain cells, hence there is no elevation of its level.

One of the major factors that can cause tissue damage initiated by head trauma is lipid peroxidation (Demir et al., 2013). There are intracellular lactate production and hyperglycaemia, during the acute ischemic phase of brain injury, which leads to subsequent development of reactive oxygen species ( $\mathrm{Li}$ et al., 1999 and Diaz Parejo et al., 2003).

In this study, MDA, as an indicator of lipid peroxidation, was significantly elevated in severe TBI patients as compared to moderate TBI patients. While, this elevation was nonsignificant in moderate TBI patients, it was significantly elevated in severe TBI patients when compared to control. Regarding superoxide dismutase (SOD) and glutathione (GSH) as antioxidants, SOD concentration was significantly decreased in severe TBI patients as compared to moderate TBI patients .Glutathione, was highly significant decreased in severe TBI patients as compared to moderate TBI patients. Both, SOD and GSH, were highly significantly decreased when compared to control.

Similarly, Kasprzak et al. (2001) demonstrated that increased erythrocyte TBARS concentrations were correlated with the severity of injury in the patients with brain contusion. This elevation in lipid peroxidation was 
associated with unfavorable neurological outcome (Di Battista et al., 2015).

Rodriguez et al. (2004) stated that when the tissues are exposed to oxidative stress, they increase the expression of antioxidant enzymes as a compensatory mechanism against free radical-mediated damage. And they ascertained that the increased activity of the antioxidant enzymes may be inadequate to counteract the potential damage in many conditions of oxidative stress. So, the decreased levels of antioxidants in the presented study lead to highly elevated oxidative stress conditions.

This consistent with Ozdemir et al. (2005) who found that whereas TBI significantly increased thiobarbituric acid reactive substances (TBARS) levels, there was no compensatory increase in SOD and glutathione peroxidase (GPx) 24 hours after TBI in 7-day-old rats. In addition, the depleted level of glutathione in the tissues may lead to progressing oxidative stress and more complications (Arent et al., 2014 and Rai et al., 2017).

Regarding visfatin gene, in the presented study, its $\mathrm{C}>\mathrm{T}$ locus had three genotypes: TT was characterized at $283 \mathrm{bp}$, TC at 283bp, $218 \mathrm{bp}$ and $\mathrm{CC}$ at $218 \mathrm{bp}$. Patients with severe TBI were mostly CC genotype, while moderate TBI patients were TC and TT genotype carriers

This genotype seemed to have a role in determination of plasma visfatin level (Weng et al., 2003). In addition, Xiao et al. (2015) indicated that higher visfatin levels and $\mathrm{CC}$ genotype were associated with traumatic brain injury among Chinese population. As well as Ye et al. (2005) showed that visfatin was reduced in patients with the $\mathrm{T}$ variant.
Whereas, Tokunaga et al. (2008) suggested that this variation might be not functional among Japanese. Differences in experimental conditions, ethnicity and geographic variation may account for this discrepancy.

The genotype CC had the highest plasma visfatin, enolase, MDA concentrations and lowest SOD and GSH. While this concentration between the variant genotypes CT and TT did not differ significantly in the presented results.

Studies have shown that clinical practice guidelines have an impact on the outcomes of trauma cases (Hyams et al., 1995). Hence, it is of great importance to incorporate new modalities of diagnosis and prognosis in forensic evaluation of medical care (Shahin et al., 2016).

\section{Conclusion}

Traumatic brain injury can release number of injury related molecules which are easily assessed in the peripheral blood. These biomarkers could facilitate diagnosis and may hold promise in the clinical management of patients. This research studied the predictive performance of some circulating biomarkers which reflect specific pathological mechanisms including neuro inflammation, neuron injury and oxidative damage in moderate to severe traumatic brain injury patients. Expression of visfatin and its $\mathrm{CC}$ gene mutation in patients with traumatic brain injury were closely related to the severity of TBI.

\section{Recommendations}

Studying the prognostic utility of the change in blood levels of these biomarkers in mild injured patients, for longer-term outcome and in large enough sample size. 
References

Abdel-Hameed, S.Y.; Ibrahim, A.K.; Thabet, H.Z.; et al. (2017): "Patterns of traumatic injuries and mortality in tertiary trauma center, Assiut University hospitals (from 2005 to 2012)". Egypt J. Forensic Sci. Appli. Toxicol., 17 (1):89-108.

Anand, N. and Stead, L.G. (2005): "Neuron-specific enolase as a marker for acute ischemic stroke: a systematic review". Cerebrovasc. Dis., 20 (4):213-219.

Arent, A.M.; de Souza, L.F.; Walz, R.; et al. (2014): "Perspectives on molecular biomarkers of oxidative stress and antioxidant strategies in traumatic brain injury". Biomed Res. Int.: 723060. In Hindawi Publishing Corporation

http://dx.doi.org/10.1155/2014/723060 (Accessed in 10/1/2018).

Balestreri, M.; Czosnyka, M.; Chatfield, D.A.; et al. (2004): "Predictive value of Glasgow Coma Scale after brain trauma: change in trend over the past ten years". J. Neurol. Neurosurg. Psychiatry, 75(1):161-162.

Bogoslovsky, T.; Gill, J.; Jeromin, A.; et al. (2016): "Fluid biomarkers of traumatic brain injury and intended context of use". Diagnostics (Basel), 6(4):E37.

Böhmer, A.E.; Oses, J.P.; Schmidt, A.P.; et al. (2011): "Neuron-specific enolase, S100B, and glial fibrillary acidic protein levels as outcome predictors in patients with severe traumatic brain injury". Neurosurgery, 68 (6):16241630; discussion1630-1631.
Chen, J.; Weng, J.F.; Hong, W.C.; et al. (2012): "Change in plasma visfatin level after severe traumatic brain injury". Peptides, 38 (1): 8-12.

Cheng, F.; Yuan, Q.; Yang, J.; et al. (2014): "The prognostic value of serum neuronspecific enolase in traumatic brain injury: systematic review and meta-analysis". PLoS One, 9(9):e106680.

de Kruijk, J.R.; Leffers, P.; Menheere, P.P.; et al. (2001): "S-100B and neuronspecific enolase in serum of mild traumatic brain injury patients. A comparison with health controls". Acta Neurol. Scand., 103(3):175-179.

Demir, I.; Kiymaz, N.; Gudu, B.O.; et al. (2013): "Study of the neuroprotective effect of ginseng on superoxide dismutase (SOD) and glutathione peroxidase (GSH-Px) levels in experimental diffuse head trauma". Acta Neurochir, 155(5):913-922.

Di Battista, A.P.; Buonora, J.E.; Rhind, S.G.; et al. (2015): "Blood biomarkers in moderate-to-severe traumatic brain injury: potential utility of a multi-marker approach in characterizing outcome". Front. Neurol., 6:110.

Diaz-Parejo, P.; Ståhl, N.; Xu, W.; et al. (2003): "Cerebral energy metabolism during transient hyperglycemia in patients with severe brain trauma". Intensive Care Med., 29(4):544-550.

Guzel, A.; Er, U.; Tatli, M.; et al. (2008): "Serum neuron-specific enolase as a predictor of short-term outcome and its correlation with Glasgow Coma Scale in traumatic brain injury". Neurosurg. Rev., 31(4):439-444.

Huang, Q.; Dai, W.M.; Jie, Y.Q.; et al. (2013): "High concentrations of visfatin in the peripheral blood of patients with acute 
basal ganglia hemorrhage are associated with poor outcome". Peptides, 39: 55-58.

Hyams, A.L.; Brandenburg, J.A.; Lipstiz, S.R.; et al. (1995): "Practice guidelines and malpractice litigation: a two way street". Ann. Intern. Med., 122(6):450-455.

Jollow, D.J.; Mitchell, J.R.; Zampaglione, N.; et al. (1974): "Bromobenzene induced liver necrosis: Protective role of glutathione and evidence for 3, 4 bromobenzene oxide as the hepatotoxic metabolite". Pharmacology, 11(3):151-169.

Kasprzak, H.A.; Wozniak, A.; Drewa, G.; et al. (2001): "Enhanced lipid peroxidation processes in patients after brain contusion". J. Neurotrauma, 18(8): 793-797.

Kawata, K.; Liu, C.Y.; Merkel, S.F.; et al. (2016): "Blood biomarkers for brain injury: What are we measuring" ? Neurosci. Biobehav. Rev., 68: 460473.

Kövesdi, E.; Lückl, J.; Bukovics, P.; et al. (2010): "Update on protein biomarkers in traumatic brain injury with emphasis on clinical use in adults and pediatrics". Acta Neurochir. (Wien), 152(1):1-17.

Lee, H.H.; Lee, W.H.; Seo, H.G.; et al. (2017): "Current state and prospects of development of blood-based biomarkers for mild traumatic brain injury". Brain Neurorehabil., 10(1):e3.

Li, P.A.; Liu, G.J.; He, Q.P.; et al. (1999): "Production of hydroxyl free radical by brain tissues in hyperglycemic rats subjected to transient forebrain ischemia". Free Radic. Biol. Med., 27(9-10):1033-1040.
Lozano, D.; Gonzales-Portillo, G.S.; Acosta, S.; (2015): "Neuroinflammatory responses to traumatic brain injury: etiology, clinical consequences, and therapeutic opportunities". Neuropsychiatr. Dis. Treat., 11: 97-106.

McKeating, E.G.; Andrews, P.J.; Mascia, L. (1998): "Relationship of neuron specific enolase and protein S-100 concentrations in systemic and jugular venous serum to injury severity and outcome after traumatic brain injury". Acta Neurochir. Suppl., 71:117-119.

Meric, E.; Gunduz, A.; Turedi, S.; et al. (2010): "The prognostic value of neuronspecific enolase in head trauma patients". J. Emerg. Med., 38 (3):297-301.

Misra, H.P. and Fridovich, I. (1972): "The role of superoxide anion in the autoxidation of epinephrine and a simple assay for superoxide dismutase". J. Biol. Chem., 247 (10):3170-3175.

Mushkudiani, N.A.; Hukkelhoven, C.W.; Hernández, A.V.; et al. (2008): "A systematic review finds methodological improvements necessary for prognostic models in determining traumatic brain injury outcomes". J. Clin. Epidemiol., 61(4): 331-343.

Ogata, M. and Tsuganezawa, O. (1999): "Neuron-specific enolase as an effective immunohistochemical marker for injured axons after fatal brain injury". Int. J. Legal Med., 113(1):19-25.

Ohkawa, H.; Ohishi, N. and Yagi, K. (1979): "Assay for lipid peroxides in animal by thiobarbituric acid reaction". Anal. Biochem. 95 (2):351-358.

Ozdemir, D.; Uysal, N.; Gonenc, S.; et al. (2005): "Effect of melatonin on brain oxidative damage induced by traumatic 
brain injury in immature rats". Physiol. Res., 54 (6): 631-637.

Papa, L.; Edwards, D. and Ramia, M. (2015): Exploring serum biomarkers for mild traumatic brain injury. In: Brain Neurotrauma Molecular, Neuropsychological, and Rehabilitation Aspects. Chapter 22, Editor: Kobeissy, F.H.; PhD. Boca Raton (FL): Frontiers in Neuro-engineering, CRC Press/Taylor \& Francis.

Rai, V.; Phang, L.; Sia, S.; et al. (2017): "Effects of immunonutrition on biomarkers in traumatic brain injury patients in Malaysia: a prospective randomized controlled trial". BMC Anesthesiol., 17(1):81.

Raj, R.; Siironen, J.; Kivisaari, R.; et al. (2014): "Predicting outcome after traumatic brain injury: development of prognostic scores based on the IMPACT and the APACHE II". J. Neurotrauma, 31(20):1721-1732.

Rodriguez, C.; Mayo, J.C.; Sainz, R.M.; et al. (2004): "Regulation of antioxidant enzymes: a significant role for melatonin". J. Pineal Res., 36(1): 1-9.

Roozenbeek, B.; Maas, A.I. and Menon, D.K. (2013): "Changing patterns in the epidemiology of traumatic brain injury". Nat. Rev. Neurol., 9 (4): 231236.

Schaan, M.; Jaksche, H. and Boszczyk, B. (2002): "Predictors of outcome in head injury: proposal of a new scaling system”. J. Trauma, 52 (4):667-674.

Selakovic, V.; Raicevic, R. and Radenovic, L. (2005): "The increase of neuronspecific enolase in cerebrospinal fluid and plasma as a marker of neuronal damage in patients with acute brain infarction”. J. Clin. Neurosci., 12(5):542547.

Shahim, P.; Tegner, Y.; Wilson, D.H.; et al. (2014): "Blood biomarkers for brain injury in concussed professional ice hockey players". JAMA Neurol., 71(6):684-692.

Shahin, M.M.; Fathy, A.S. and Shadad, M.N. (2016): "Clinical and forensic importance of $\mathrm{S} 100 \beta$ protein for prediction of outcome and evaluation of medical care in mild to moderate head injuries". Mansoura J. Forensic Med. Clin. Toxicol., 28(1):57-72.

Siman, R.; Giovannone, N.; Hanten, G.; et al. (2013): "Evidence that the blood biomarker SNTF predicts brain imaging changes and persistent cognitive dysfunction in mild TBI patients". Front. Neurol., 4:190.

Skogseid, I.M.; Nordby, H.K.; Urdal, P.; et al. (1992): "Increased serum creatine kinase $\mathrm{BB}$ and neuron specific enolase following head injury indicates brain damage". Acta Neurochir. (Wien), 115 (3-4):106-111.

Strathmann, F.G.; Schulte, S.; Goerl, K.; et al. (2014): "Blood-based biomarkers for traumatic brain injury: evaluation of research approaches, available methods and potential utility from the clinician and clinical laboratory perspectives". Clin Biochem., 47(10-11):876-888.

Tokunaga, A.; Miura, A.; Okauchi, Y.; et al. (2008): "The -1535 promoter variant of the visfatin gene is associated with serum triglyceride and HDL-cholesterol levels in Japanese subjects". Endocr. J., 55(1):205-212.

Undén, L.; Calcagnile, O.; Undén, J..; et al. (2015): "Validation of the Scandinavian guidelines for initial management of 
minimal, mild and moderate traumatic brain injury in adults". BMC Med., 13:292.

Vos, P.E.; Lamers, K.J.; Hendriks, J.C.; et al. (2004): "Glial and neuronal proteins in serum predict outcome after severe traumatic brain injury". Neurology, 62(8):1303-1310.

Wang, L.S.; Yan, J.J.; Tang, N.P.; et al. (2011): "A polymorphism in the visfatin gene promoter is related to decreased plasma levels of inflammatory markers in patients with coronary artery disease". Mol. Biol. Rep., 38 (2):819-825.

Weng, J.F.; Chen, J.; Hong, W.C.; et al. (2013): "Plasma visfatin, associated with a genetic polymorphism $-1535 \mathrm{C}>\mathrm{T}$, is correlated with $\mathrm{C}$ - reactive protein in Chinese Han patients with traumatic brain injury". Peptides, 40: 8-12.

Woertgen, C.; Rothoerl, R.D. and Brawanski, A. (2001): "Neuron-specific enolase serum levels after controlled cortical impact injury in the rat". J. Neurotrauma, 18(5):569-573.

Xiao, H.; Cheng, M.; Zhang, L.J.; et al. (2015): "Visfatin expression and genetic polymorphism in patients with traumatic brain injury". Int. J. Clin. Exp. Med., 8(6):9799-9804.

Ye, S.Q.; Simon, B.A.; Maloney, J.P.; et al. (2005): "Pre- B-cell colony-enhancing factor as a potential novel biomarker in acute lung injury”. Am. J. Respir. Crit. Care Med., 171(4):361-370. 


\title{
دور بعض المؤشرات الكيميائية الحيوية والجينية فى التنبؤ بشدة إصابة الدماغ
}

\section{'نجوى محمود غندور' ، محمد على رجائي ، رندة ثمير حنا'}

\author{
'قسم الطب الثرعي والسموم الإكلينيكية ، " قسم جراحة الأعصاب ، “ّمسم الكيمياء الحيوية

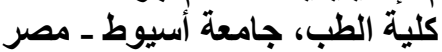

إصابة الدماغ هي واحدة من الإصابات الثائعة المرتبطة بالوفيات والمرض. تعتبر المؤشر ات الحيوية فى إتى

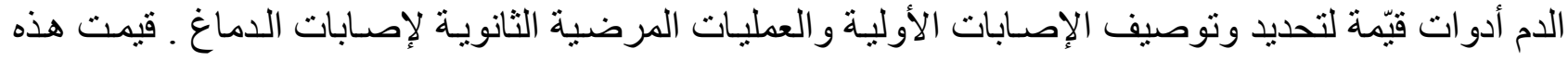
الدر اسـة أداء فيزفـاتين المطـور حديثًا والمؤشـر الجينـي المـرتبط بـهـ وارتباطـه بالمؤشـرات الكيميائيـة الحيويـة الأخرى التي تدور بالدم والتي تعكس آليات مرضية محددة بمـا في ذلك التهاب الأعصـاب و إصـابة الخلايـا العصبية والضرر التأكسدي في مرضـى إصـابات الدماغ المعتدلة والثديدة. تم أخذ عينـات الدم مـن مرضسى

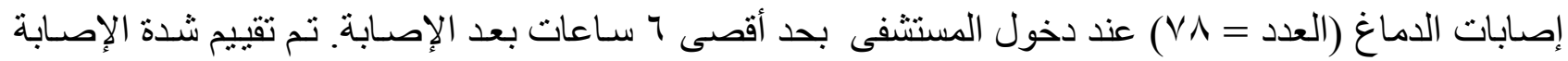
و النتائج العصبية باستخدام مقياس غلاسكو للغيبوبة ، وقياس فيزفاتين وجيناته و إينو لاز المعين للخلايـا العصبية

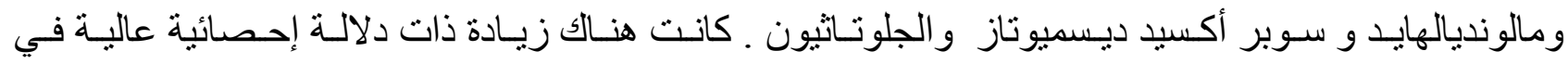

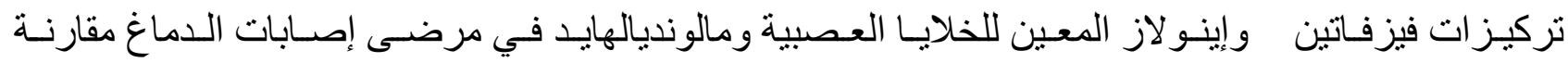
بالمجمو عة الضابطة في حين انخفض تركيز سوبر أكسيد ديسموتاز و الجلوتاثيون في مرضسى إصـابات الدماغ مقارنة بالمجمو عة الضابطة. ارتبط فيزفاتين بعلاقة إيجابية مع إينولاز المعين للخلايا العصبية ومالونديالهايد في

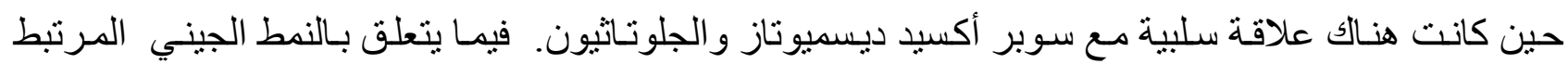

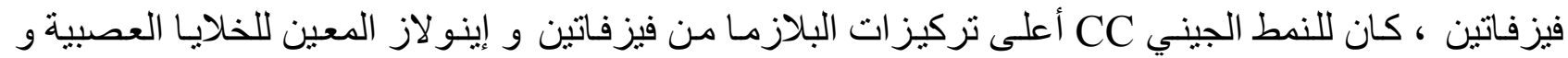

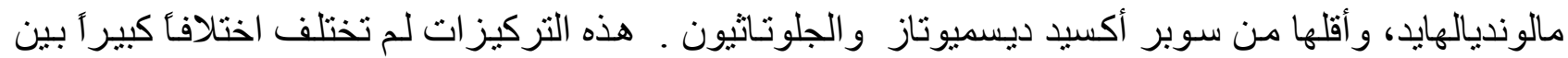

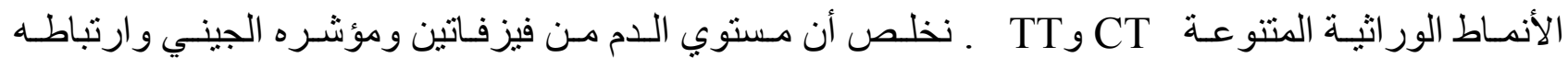

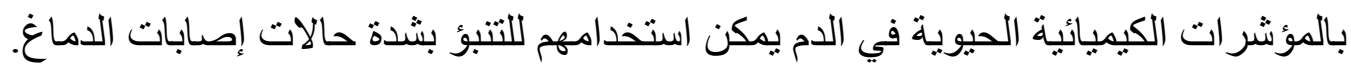

